\title{
The Religiosity Behavior of Adolescence Case Study in Greece
}

\author{
Maria Rantzou', Eleni Mpellou ${ }^{2}$ \\ ${ }^{1}$ Faculty of Theology, School of Theology, Aristotle University of Thessaloniki, Thessaloniki, Greece \\ ${ }^{2}$ Religious Education, Thessaloniki, Greece \\ Email: rantzou@theo.auth.gr, e.mpellou@gmail.com
}

How to cite this paper: Rantzou, M., \& Mpellou, E. (2021). The Religiosity Behavior of Adolescence Case Study in Greece. Creative Education, 12, 797-808. https://doi.org/10.4236/ce.2021.124056

Received: November 18, 2020

Accepted: April 17, 2021

Published: April 20, 2021

Copyright (c) 2021 by author(s) and Scientific Research Publishing Inc. This work is licensed under the Creative Commons Attribution International License (CC BY 4.0).

http://creativecommons.org/licenses/by/4.0/

\begin{abstract}
The aim of the article is to explore the religiosity of adolescents, focusing mainly on the attitudes and behaviors of children aged 13 - 15 years. The research design was based on the assumption that adolescents have become less and less religious in recent decades. The research in the relevant literature focused on specific theories and assumptions that formed the theoretical framework of the research. The sample of the research is students aged 13, 14 and 15 who were attending a High School in the prefecture of Thessaloniki during the school year 2019-2020. This High School was selected because it met all the formal requirements for conducting the research and had all the essential characteristics of a school as its students came from families with average economic, social and educational range. The sample consisted of 89 students ( 31 boys and 58 girls). The structured questionnaire was chosen as a research tool for data collection. Factor analysis (Varimax method) was used. The appropriateness of the data for the application of factor analysis was found through the Kaiser-Meyer-Olkin statistical measure (values from 0 to 1) and the Bartlett sphericity test. The analysis of the research variables showed that: Religion does not seem to be a practical part of their daily life. Religion is quite high in their value system and is a determining factor of their identity. Adolescents believe, however, without participating in religious rituals and events and without fully sharing the way of life dictated by religion.
\end{abstract}

\section{Keywords}

Religiosity, Adolescence, Faith, Christian Ethics

\section{Introduction}

The sciences of Sociology, History, Anthropology, Archaeology, Psychology, 
Medicine and Neurobiology study religiosity systematically and approach it as a pan-human timeless phenomenon, that is not easily delimited and is related to both biological and social factors (Newberg \& Waldman, 2009: pp. 12-19). It is directly related to faith and is cultivated through moral education in general, and through religious education within the family, the school, the social and the ecclesiastical environment, in particular.

Religiosity is associated with the concept of religion, the content of which is not easy to determine. Approaching it from the point of view of sociology of religion, it is perceived within the social context, in relation to its social function and not to its religious content. It concerns the (self) worship of the community and has three fundamental functions: social cohesion, social control and the giving of meaning and purpose to human existence (Durkheim, 1995: p. 234). In another case, religion is a system of symbols defining the worldview of each individual. Religion has seven dimensions: the practical - ritual (prayer, pilgrimages, ceremonies), the experiential - emotional, (religious experiences, mystical traditions) the narrative - mythical (systematic recordings of religious perceptions, oral traditions), the dogmatic - philosophical (formal teachings, interpretation of teachings, the importance of dogmatic differences on religion), the ethical - legal (rules), the social - institutional (interactions between people and religions) and the material (structures, ecclesiastical art, painting, architecture, music and crafts, the sacred places) (Willaime, 2004: p. 94).

\section{Conceptual Clarification of the Term Religiosity}

At this point, it is important to be noted that there is no single definition of religiosity, that is commonly accepted by all researchers and the scientific community (Klaasen et al. 2009), given that religion presents multidimensional nature, but also people show an inability to grasp its full extent, the transcendental (Gross, 2006: p. 121), while the investigation of the phenomenon and the drawing of conclusions depends to a large extent on the subjective opinion of each researcher, his own thoughts and prejudices (Varelis, 2000: pp. 11-12).

The roots of religiosity can be traced to the innermost, to the internal aspects of the human nature. Evidence for the piety of humans already exist by the ancient writers, who spoke about the religious behavior of humans. According to Ubani and Tiri (2006), there are three variables of religiosity, which include: 1) the institutional view, 2) the humanitarian understanding and 3) the supernatural perception of it. At the same time, its classification is divided into existential, multidimensional and general (Wong et al. 2006) or, according to a different approach, into behavioral, related to worship, and subjective, which refers to the values, the spirituality and the importance (Walker et al. 2007).

The term religiosity refers to the mental functions collectively, which contribute to the connection of human with the transcendent truth of God. Religiosity is an inner tendency, that is inherent in people, an inner experience of a personal tone, which develops with the help of religious learning and cognitive processing of the assumptions of faith. At the same time, religiosity is the emotional ap- 
proach to religious reality, as well as the voluntary practical behavior of man, related to his religious faith (Grom, 2007). Religiosity is an extremely broad term, while it is not found in any specific point of human consciousness. It does not come from a special mental function, but it has its own physiognomy and its own characteristics. Key features of religiosity include:

- The experience of religiosity as something that transcends the boundaries of secularism and transports people to a reality, that is beyond the boundaries of the world.

- The transcendence of the cosmic realm, because the divine being is the existential source of life, which is visible through consciousness.

- People's participation in life, which is based on emotions and voluntary actions aimed at overcoming the ego and accepting the trust, the hope, the love and the peace that result from the relationship with God (Marks, 2009).

From the point of view of sociology and history, it is argued that religious emotion in its most primitive form, took the form of an inward fear of man towards natural phenomena and the destruction they caused to his environment. With the passage of time and the increase of understanding of nature and its phenomena, as well as with the transition of people in the social and cultural life, fear gradually receded and was replaced by different emotions. Love, respect and devotion to the divine came to replace fear and, in this way, the religious feeling of humans began to take shape. According to another view, religious feeling stems from psychological needs, that can be satisfied through religion, for example, the need for affection received from the God of love, the need for knowledge that is satisfied through the concept of the omniscient God, the need for redemption from guilt through divine forgiveness (Kakavoulis, 1994).

\section{Religiosity in Orthodox Theology}

Starting the theological investigation, the term religiosity must be separated from the term ecclesiology (Giddens, 2009: pp. 121-123; Gioultsis, 1996: pp. 39-40; Petrou, 2005: p. 254). In the second case, reference is made to the extent to which the individual participates in ceremonies related to church life (Tsironis, 2012: p. 68). In the first case, however, the term religiosity is a broader concept, which contains different aspects.

Initially, the context of religiosity includes the participation of the individual in religious-type rituals, such as, for example, the Divine Liturgy, his knowledge of the doctrines of religion and the rules that govern it, the religious community, its structures and hierarchy, the support of the main beliefs of the religious body, and the integration of religion in everyday life. The recording of various aspects of religiosity is measurable on the basis of modern scientific research and can be reflected in quantitatively or qualitatively oriented variables (King \& Crowther, 2004; Hill \& Pargament, 2003). This, however, concerns only the features that are accessible, since the religious experience is also associated with internal dimensions, that cannot be the subject of recording and analysis.

Religiosity, however, does not operate independently of the Church, which is a 
workshop of holiness, in which man is asked to be completed in the name of Jesus Christ, guided and enlightened by the Holy Spirit. The religious experience offered to the Body of the Church goes beyond the concept of religiosity, but also of spirituality. Therefore, in the Orthodox Church we talk about spirituality or holy spiritual life. And the spirituality is the enlightenment of the existence by the Holy Spirit, that is experienced in the religious experience of man as a member of the Church (Stogiannidis, 2016: pp. 404-406).

The theological approach to the concept of religiosity focuses primarily on the possibility it provides to the believer to communicate with God, without the mediation of a third person. In this sense, religiosity can be understood as the acceptance of a system of beliefs associated with specific denominations, rituals and practices (Brennan, 2004), or as the systematized or standardized way, in which one accepts and externalizes religious beliefs and rituals associated with a particular religion (Shafranske \& Malony, 1990: pp. 72-78).

As it becomes clear according to the above mentioned, different definitions of religiosity have been formulated in relation to its theological dimension. However, the term has aroused the interest of other scientific fields, as presented in the following sections, while modern studies emphasize the need for its further investigation, in order to better understand its different dimensions, but also their effect on the individual (Sclehofer et al., 2008; Zinnbauer \& Pargament, 2005).

The cognitive side of religiosity, which is related to the ability of the child and the adolescent to grasp and understand religious concepts, is developed at different stages. One of the basic stages is the religious thought, which is developed after the 13th or 14th year, when the adolescent is able to apply his logic to abstract concepts, which include religious truths. He gradually acquires the religious thought, which helps him penetrate into the deeper meaning and the interpretation of the religious truth. Religiosity, according to Kohlberg, is an integral part of the content of moral thought. Thus, the gradual moral development is absolutely necessary, however it is not enough for the development of religiosity, since the ultimate purpose of religious development is the deeper meaning of life (Kakavoulis, 1994).

Regarding Orthodox faith, St. Vasilios and St. John Chrysostom had intense pedagogical activity and thought and dealt with issues concerning, among others, adolescents and the development of their religiosity. St. John Chrysostom emphasizes in his work the importance of the role of the Church to the education of adolescents, as he considers that it is the most important "school", that aims at the redemption of the soul (Ioannis Chrysostomos PG 47, 368A). The work of the Church, of course, is addressed to every believer, regardless of age. However, it is also extremely important in the case of young people. In fact, through teaching, it is possible to transmit the knowledge related to worship and Christian ethics and, in collaboration with the school, but also with the family of the adolescents, to achieve the strengthening of their religiosity (Kroustalakis, 2006). 
The importance of the role of the Church and the school is also emphasized by St. Vasilios, who believes, that through them, it is possible to enhance the education of children and adolescents and their religiosity. For this reason, he proceeded to the establishment of monastic schools and regulated their operation, in such a way, in order to assist the work of educators and to enable the education of future citizens on the basis of Christian ethics and the creation of "perfect Christians". Within these schools, students followed the same curriculum as in formal schools, but, in addition, they were taught about the Bible and the patriarchal texts, they acquired spiritual cultivation, and they learned the virtues of Christianity. The development of religiosity through education is considered necessary for children, whose education, according to the St. Vasilios, should begin at a very young age, at home, which is the first "school", and, by extension, for adolescents, as it is considered a necessary condition for their general development (Mavridis, 2005).

In addition to the above, as far as Orthodox Theology is concerned, there is evidence indicative of the way in which religiosity is perceived, which are found in both the Old and New Testaments. Starting with the Old Testament, there is the element of sacrifice, which demonstrates religiosity. A typical example is the sacrifice of Abraham (Gen. 22: 1-19), who is asked by God to sacrifice his son, Isaac, in order to prove his faith. Abraham would indeed fulfill the Lord's command, but at the last moment an angel stopped him and urged him to slaughter an animal instead of his own child, because he had already proved his faith. The subject of sacrifice is also addressed in the 2nd book of the Old Testament (Exodus), in which references are made to the outdoor altars built by the Israelites on their way out of Egypt until their arrival in the Promised Land.

In addition, a proof of religiosity and the way in which it was expressed in the Old Testament years, is the construction of a portable temple, known as the Tent of Martyrdom, in the desert. The tablets with the 10 Commandments that God gave to Moses, were placed inside the temple, after they were placed inside the Ark of the Covenant. It was carried by the Israelites until they reached the Promised Land (Ex. 19-40). There, King David of Israel wanted to build a permanent temple on the hill of Moriah. After first redeeming him, he offered a sacrifice to God and built the altar. His desire, however, was to build a majestic temple, the construction of which he entrusted to his son Solomon. Finally, when Moses was slow to return from the mountain, where God called him to receive the 10 commandments, Israelites asked Aaron to create a god, who will help them get out of the wilderness. He made a golden calf, which they worshiped and believed would help them finally reach the Promised Land (Ex. 32: 1-35). Elements of religiosity are also found in the text of the New Testament. Initially, in Sunday prayer, the disciples ask Christ to show them how to pray like him, and as a result, he recites the "Our Father" (Matt. 6: 9-15; Luke 11: 1-4). Jesus then joins the other Israelites in the Feast of Tabernacles (John 7: 10-13).

The way of expressing religiosity is also demonstrated in the question about 
the fast of the disciples of John and the Pharisees, addressed to Jesus (Mark 2: 18-20), but also in the communion of the body and the blood of Christ to his disciples at the Last Supper phrase "Take, eat; this is my body." as well as: This is my blood of the covenant, which is poured out for many".

\section{The Development of Religiosity in Adolescence}

According to Goldman, religious development can be divided into three periods. The first period is the pre-collective period of "child religiosity", the second of the specific religious thought and the third of the abstract religious thought (Oser \& Scarlett, 1991; Vasilopoulos, 1996).

Religiosity consists of three main areas: 1) cognitive, related to the learning and mental abilities, necessary to grasp religious concepts and knowledge, and be understood by the individual, 2) emotional or experiential, related to the set of internal experiences and situations, that the individual experiences, in relation to religious concepts and knowledge and 3) the area of religious behavior, which includes the ways in which man can externalize his religious experiences. This distinction, of course, is made solely for reasons related to the religious development of the individual. In fact, religiosity is a single mental event that does not get separated. Religiosity is a field that cannot be understood from a very young age. A child does not have the cognitive skills and conditions required to be able to comprehend and process the religious concepts he encounters. At infancy, from the 1st to the 3rd year of age, the person gradually prepares for the appearance and later for the development of religiosity. This happens through a set of unconscious developmental processes that prepare for the emergence of conscious religiosity. After the 3rd year (during infancy up to the 6th year) the cognitive, social and emotional conditions required for the child, in order to be able to perceive and respond to religious stimuli gradually develop, after conceiving with its cognitive potential the religious concepts (Boyatzis, 2005).

Then, during childhood (from the 7th to the 12th year of age) the child matures and can comprehend all religious concepts. At the same time, he acquires more relevant experiences to religious life, either from his immediate environment or from the teaching of the school (Easton, et al. 2019). It is the family that, first of all, being the example to the teenager, pushes him to gain experiences that will provide him with the possibilities that are necessary for the knowledge of the objective world, of others but also of himself. It is the family itself that can transmit the Christian faith to him through its behavior (Kogoulis, 2008: p. 328). Over time the adolescent raises metaphysical questions related to the existence of God and his attributes, nature, human, life and death. The answers he receives help him to shape his thinking about religious concepts (Boyatzis, 2005).

\section{Empirical Research}

\subsection{Objective of the Research}

As part of the project, a case study was conducted on high school students in the 
city of Thessaloniki, regarding the religiosity of adolescents. Adolescents' religiosity is an extremely interesting field, as it concerns the way in which they approach a sensitive issue, such as religion. The teenager seeks his identity, to build his image, to discover the meaning of his life. The aim of the research is to find out the adolescents' attitudes and views towards the religion and the church.

\subsection{The Research Cases}

The most important hypotheses of the present research were formulated in accordance with the above written:

- The gender and the age of the adolescent contribute to the appearance and manifestation of attitudes and behaviors towards religion.

- The level of education of the parents, mother and father, is a factor that contributes and characterizes the attitude of the adolescent in the field of religiosity.

- The family environment in which the adolescent lives, i.e. if he grows up with one or both parents, as well as the presence of the grandfather or grandmother in the family, plays an important role in the expression of religiosity and the manifestation of his faith.

- The presence of siblings in the family is an important factor in the general attitude and expression of the adolescent towards religion.

- The teenager's birth order plays a role in the manifestation of his religiosity.

\subsection{The Subjects of the Research}

The subjects of the research in the present case study "Religiosity of adolescents" are children of school age 13,14, and 15 years old, who attended secondary school and high school in the center of Thessaloniki, during school year 2019-2020. This High School was selected, because it met all the formal requirements for conducting research and had all the essential characteristics of a school, given that its students came from families with an average economic, social and educational background. The school population was 137 students, and the distribution was 60 boys and 77 girls. The school also had 21 foreign students. In the above set of students, the completed questionnaires were 89,31 by boys and 58 by girls.

\subsection{Measurement tool and Description of the Questionnaire}

The questionnaire was used as a measurement tool in the research. The questionnaire is divided into two parts and consists of 34 variables-questions-closed type sentences. In the first part, the adolescents were asked to respond to seven demographic characteristics (gender, age, educational level of mother, educational level of father, guardians, existence of siblings, order of birth). Following are the 27 questions in the second part, related to the religiosity of the teenagers. In each sentence the answers follow the same five-point Likert scale: I totally disagree, I disagree, I neither agree nor disagree, I agree, I totally agree. 


\subsection{Analysis of Results}

After data collection, their analysis was performed. The completed questionnaires, as mentioned, were 89 . Their validity was checked and then a computer was used to enter the details of each answer.

In order to draw as reliable conclusions as possible about the religiosity of adolescents, it was deemed necessary to group the proposals, using factor analysis (Dafermos, 2009). The Varimax method was used for this purpose. The suitability of the data for the application of factor analysis can be determined through the statistical measure of Kaiser-Meyer-Olkin, with values from 0 to 1. Specifically, values greater than 0.7 indicate that the factor analysis will provide correct grouping. The same can be tested with the Bartlett sphericity test, in which, if the $\mathrm{p}$ value of the test is less than 0.05 , there is a strong indication that the factor analysis is worth applying to the questionnaire proposals.

In this case, both the Kaiser-Meyer-Olkin index $(\mathrm{KMO}=0.895)$ and the results from Bartlett's sphericity test ( $\mathrm{x} 2(351)=1859.347, p<0.001)$ suggest that the data are suitable for the application of factor analysis. In fact, four groups of proposals emerged, that explain a total of $70.34 \%$ of the variability of the answers given by the members of the sample. The next table (Table 1) lists the questionnaire proposals and the uploads of each proposal to each of the groups, resulting from the Varimax method. However, loads are omitted in cases when they are less than 0.4 , because such values are considered too low for classification of proposals into groups. Also, in cases when a proposal presents high loads (over 0.4 ) in more than one group, it is eventually included in the group, at which it shows the highest load. Therefore, the resulting groups refer to: "Faith Aid" (1), "Interest in Religion and the Mysteries" (2), "The Impact of Faith on Everyday Decisions" (3) and "Public Expression of Religious beliefs" (4). It is worth noting that sentence 21 ("I like participating in the sacrament of Holy Communion") is classified in the first group, according to the factor analysis, but we eventually classified it in the second group, as its content is more relevant to the proposals of this group.

Afterwards, a reliability analysis was performed to determine whether the groups indicated by the Varimax method at the factor analysis stage are indeed valid. Essentially, with the reliability analysis, an attempt is made to determine if the respondents answer in the same way to all the proposals of each group, ie if the group shows high internal cohesion. This investigation is done with the statistical index called Cronbach's alpha. This is a statistical measure with values from 0 to 1 , with values exceeding 0.7 being considered satisfactory for the high reliability of the team. However, there are some stricter authors who accept the value of 0.8 as the lower limit of reliability. A necessary condition for the correct application of the index is that there is either positive or negative content in all the proposals of the group, that is examined each time in terms of reliability. For this purpose, sentences $2,3,5,11,12,15,23$ were reversed, as they had negative content. Eventually, all the proposals ended up concerning the interest and the commitment of teenagers to religion. 
Table 2 shows the values of the reliability index for each of the previous four groups of proposals. As it seems, the first three proposals meet the reliability criterion (alpha coefficient greater than 0.7 ), but the fourth group does not exceed the lower value of 0.7 . However, this can be justified by the very small number of proposals of this group (2 proposals).

Table 1. Loads of suggestions on adolescent religiosity in each of the four questionnaire groups.

\begin{tabular}{|c|c|c|c|c|}
\hline \multirow{2}{*}{ SUGGESTIONS } & \multicolumn{4}{|c|}{ GROUPS } \\
\hline & 1 & 2 & 3 & 4 \\
\hline 1) The church is very important to me. & 0.665 & 0.494 & & \\
\hline 2) I find going to church a waste of time. & -0.635 & -0.513 & & \\
\hline 3) The church is outdated. & & -0.572 & & \\
\hline 4) Praying helps me a lot. & 0.823 & & & \\
\hline 5) I believe that saying prayers at school is of no use anywhere. & -0.710 & -0.400 & & \\
\hline 6) I believe that God hears prayers. & 0.894 & & & \\
\hline 7) Prayer can solve many problems. & 0.726 & & & \\
\hline 8) God is important to me. & 0.810 & & & \\
\hline 9) I really like learning about God. & 0.488 & 0.544 & & \\
\hline 10) I believe that Christ still helps people. & 0.808 & & & \\
\hline 11) I think that the Bible is outdated and that's why I find it boring to listen to. & & -0.759 & & \\
\hline 12) I find the divine liturgies boring. & & -0.722 & & \\
\hline 13) God is True to me. & 0.889 & & & \\
\hline 14) I consider my faith as a source of inspiration. & 0.544 & & & \\
\hline 15) Religion has nothing to do with my interests. & & -0.570 & & \\
\hline 16) My relationship with God is extremely important to me. & 0.828 & & & \\
\hline 17) I spend time trying to improve my understanding of faith. & & 0.616 & & \\
\hline 18) I often read informative printed material about my faith. & & 0.567 & & \\
\hline 19) I like reading the Bible. & & 0.661 & & \\
\hline 20) I like participating in the sacrament of Confession. & 0.535 & 0.548 & & \\
\hline 21) I like participating in the sacrament of Holy Communion. & 0.592 & $0.461^{*}$ & & \\
\hline 22) I am not ashamed to express my religious beliefs in public. & & & & 0.707 \\
\hline 23) I am ashamed to publicly support, in a debate, the religion I believe in. & & & & -0.754 \\
\hline 24) I believe in the existence of God and I have no doubt about it. & 0.822 & & & \\
\hline 25) My religious beliefs affect my daily life & & & 0.792 & \\
\hline 26) I consider my faith as a source of consolation to problems of my age. & & & 0.735 & \\
\hline 27) My faith influences me to make many of my decisions. & & & 0.761 & \\
\hline
\end{tabular}

* According to the factor analysis this sentence should have belonged to group 1, but it was classified in group 2, because its meaning is more similar to the meaning of the sentences of this group, rather than to the sentences of group 1.

Table 2. Cronbach alpha reliability values for each of the proposal groups.

\begin{tabular}{ccc}
\hline Group & Suggestions & alpha \\
\hline Help of faith & $1,2^{*}, 4,5^{*}, 6,7,8,10,13,14,16,24$ & 0.963 \\
Interest in religion and mysteries & $3^{*}, 9,11^{*}, 12^{*}, 15^{*}, 17,18,19,20,21$ & 0.906 \\
Influence of faith on everyday decisions & $25,26,27$ & 0.813 \\
Public expression of religious beliefs & $22,23^{*}$ & 0.568 \\
\hline
\end{tabular}

\footnotetext{
* These questions have been reversed.
} 


\section{Research findings}

The main conclusions that emerged from the previous analysis concerning the High School students, who attend a school in the center of Thessaloniki, can be summarized as:

- Most students believe in the help of faith and are not ashamed to express their religious beliefs in public. However, students seem to be divided over their interest in religion and the sacraments and the impact of faith on decisions that affect their daily lives.

- Boys seem to be more interested in religion and sacraments than girls. Also, younger and older students are divided in their interests, while the 14-year-old students are the ones who show the greatest devotion to Christianity, to the church and to the sacraments.

- The mother's level of education seems to have a significant effect on students' views on faith aid. In fact, children of mothers without a degree seem to believe more in the help of faith, than their other classmates. In contrast, the father's level of education does not seem to have a significant effect on any of the factors concerning students' religiosity.

- The people, who live with the students, do not seem to significantly influence their views on religion, because, no matter if they live with both parents or only with their mother, they give about the same answers. The existence of siblings is another factor that does not significantly affect students' views on religion.

- In addition, students with siblings, who are born first, seem to be less interested in religion and more ashamed of the public display of their religious beliefs, than children born second or third in a row.

- It is noteworthy that the students who believe most in the help of faith, are those who are most interested in religion and the sacraments. They are also more influenced in everyday decisions. Moreover, those who are more interested in religion and the sacraments take more seriously into account this factor, than others, in the decisions of their daily lives and are more willing to express their religious beliefs in public.

- Students' interest in religion and sacraments is the only important factor in predicting their willingness to express themselves publicly on matters of faith.

\section{Conclusion}

The study showed that adolescents display the belief that faith helps people and are not ashamed to express themselves publicly about their beliefs. However, religion does not seem to be a practical part of their daily lives. Their gender, age, their mother's educational level and their birth order seem to have a significant influence on at least one factor related to adolescent religiosity.

Because the present research effort is a case study, its results cannot be generalized, nor can they be compared with those of a generalized research, but it 
confirms the theoretical-scientific approaches, which have been extensively referred to the theoretical foundation of the approach towards the religiosity of adolescents, in various forms and under specific components.

Religion, as shown by research, is quite high in their value system and is a determining factor of their identity. This, however, does not mean making commitments and obligations to religion and to Church, because they often believe, without participating in religious rites and events and without fully sharing the way of life dictated by religion. Lastly, adolescents often seek a refuge or solutions to their problems in religion.

\section{Conflicts of Interest}

The authors declare no conflicts of interest regarding the publication of this paper.

\section{References}

Boyatzis, C. J. (2005). Religious and Spiritual Development in Childhood. In R. F. Paloutzian, \& C. L. Park (Eds.), Handbook of the Psychology of Religion and Spirituality (pp. 123-143). New York: The Guilford Press.

Brennan, M. (2004). Spirituality and Religiousness Predict Adaption to Vision Loss in Middle-Aged and Other Adults. International Journal for the Psychology of Religion, 14, 193-214. https://doi.org/10.1207/s15327582ijpr1403 4

Dafermos, B. (2009). Search for Structure in the Data of Greek Citizens, Regarding Their Attitude, in Matters of Value-Evaluation Character. Tetradia Analysis Dedomenon, 10, 113-130. (In Greek)

Durkheim, E. (1995). The Elementary Forms of Religious Life. London: George Allen \& Unwin.

Easton, C., Goodman, A., Wright, A., \& Wright, A. (2019). Critical Religious Education in Practice: A Teacher's Guide for the Secondary Classroom. London: Routledge. https://doi.org/10.4324/9781315648989

Giddens, A. (2009). Sociology. Athens: Gutenberg. (In Greek)

Gioultsis, B. (1996). Sociology of Religion. Thessaloniki: Pournara. (In Greek)

Grom, B. (2007). Religionspsychologie. Mũnchen: Kösel eBooks.

Gross, B. (2006). Forensic Examiner. Oxford: Oxford Press.

Hill, P., \& Pargament, K. (2003). Advances in the Conceptualization and Measurement of Religion and Spirituality: Implications for Physical and Mental Health Research. American Psychologist, 58, 64-74. https://doi.org/10.1037/0003-066X.58.1.64

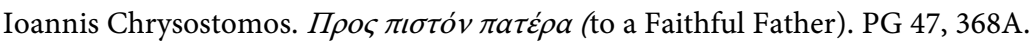

Kakavoulis, A. (1994). Ethical Development and Education. Athens: Private Edition. (In Greek)

King, J. E., \& Crowther, M. R. (2004). The Measurement of Religiosity and Spirituality: Examples and Issues from Psychology. Journal of Organizational Change Management, 17, 83-101. https://doi.org/10.1108/09534810410511314

Klaasen, D. W., Graham, M. D., \& Young, R. (2009). Spiritual/Religious Coping as Intentional Activity: An Action Theoretical Perspective. Archiv für Religionspsychologie/Archive for the Psychology of Religion, 31, 3-33. 
https://doi.org/10.1163/157361209X371456

Kogoulis, I. (2008). Catechism and Religious Education. Thessaloniki: Kyriakidis. (In Greek)

Kroustalakis, G. (2006). Education Life Course. Athens: Danias. (In Greek)

Marks, M. (2009). Religionspscychologie. Stuttgart: Kohlhammer.

Mavridis, A. (2005). Theological and Pedagogical Views in the Teaching of St. Basil. A Theoretical Analysis. Thessaloniki: Kyriakidis. (In Greek)

Newberg, A., \& Waldman, M. R. (2009). How God Changes Our Brain (Trans. A. Kelesidi). Athen: Archetypo. (In Greek)

Oser, F., \& Scarlett, G. (1991). Religious Development in Childhood and Adolescence. Hoboken, NY: Jossey-Bass.

Petrou, I. (2005). Social Theory and Contemporary Culture. Thessaloniki: Vanias. (In Greek)

Sclehofer, M. M., Omoto, A. M., \& Adelman, J. R. (2008). How Do "Religion" and "Spirituality" Differ? Lay Definitions among Older Adults. Journal for the Scientific Study of Religion, 47, 411-425. https://doi.org/10.1111/j.1468-5906.2008.00418.x

Shafranske, E. P., \& Malony, H. N. (1990). Clinical Psychologists' Religious and Spiritual Orientations and Their Practice of Psychotherapy. Psychotherapy: Theory, Research, Practice, Training, 27, 72-78. https://doi.org/10.1037/0033-3204.27.1.72

Stogiannidis, A. (2016). Didactics of the Symbol. Thessaloniki: Kyriakidi. (In Greek)

Tsironis, Ch. (2012). Research on Religiosity in Modern Greece. Epistemological Predictions. Culture and Research, 1, 68-82. (In Greek)

Ubani, M., \& Tirri, K. (2006). How Do Finnish Pre-Adolescents Perceive Religion and Spirituality. International Journal of Children's Spirituality, 11, 357-370. https://doi.org/10.1080/13644360601014106

Varelis, Th. (2000). The Development of the Child's Religiosity in School Age: A Psycho-Pedagogical View in the Context of School Education. Doctoral Thesis, Athens: National and Kapodistrian University of Athens. (In Greek)

Vasilopoulos, Ch. (1996). Religious Education and Autonomy of the Child. Thessaloniki: Kyriakidi. (In Greek)

Walker, C., Ainette, M., Willes, T., \& Mendoza, D. (2007). Religiosity and Substance Use: Test of an Indirect-Effect Model in Early and Middle Adolescence. Psychology of Addictive Behaviors, 21, 84-96. https://doi.org/10.1037/0893-164X.21.1.84

Willaime, J.-P. (2004). Sociology of Religions (Trans. A. Karastathi). A. Kardamitsa Book Institute. (In Greek) https://doi.org/10.3917/puf.willa.2004.01

Wong, Y. J., Rew, L., \& Slaikeu, K. D. (2006). A Systematic Review of Recent Research on Adolescent Religiosity/Spirituality and Mental Health. Issues in Mental Health Nursing, 27, 161-183. https://doi.org/10.1080/01612840500436941

Zinnbauer, B., \& Pargament, K. (2005). Religiousness and Spirituality. In R. F. Paloutzian, \& C. L. Park (Eds.), Handbook of the Psychology of Religion and Spirituality (pp. 21-42). New York: The Guilford Press. 